\title{
ANTHICUS TOBIAS MARSEUL, ANOTHER TRAMP SPECIES (COLEOPTERA: ANTHICIDAE)
}

\author{
By F. G. Werner \\ University of Arizona, Tucson
}

Among the rather numerous collections of Anthicidae examined by the author during the past ten years there have been small numbers of an unidentified species of Anthicus from a truly amazing variety of localities. In the United States, which yielded the first examples seen, specimens have turned up from the Atlantic to the Pacific and from New England to Florida, including such places as Catarina, Texas and the Sierra Ancha Mountains of Arizona. The author must admit that he held these specimens to represent an undescribed species and had prepared a description for publication and designated types. Then a specimen was sent from Guam, in the Marianas, others from Oahu identified as Anthicus mundulus Sharp, and, most recently, others from Jamaica and Venezuela. By this time it had become apparent that the species must have been introduced into part of the localities. Structurally, it is quite unlike any other species in the New World, especially in the details of the very elaborate structure surrounding the male primary gonopore. So an Old World source was likely.

The true identity of the species was revealed in the British Museum collection, which the author was privileged to study recently. Specimens identified as Anthicus tobias Marseul from Aden, India and Java are the same as those previously seen. The type specimen of tobias has not been examined but the specimens at hand agree perfectly with the original description. Both Anthicus mundulus Sharp and $A$. cervinus LaFerté, under whose names most specimens have been misidentified, are quite different.

In the United States, at least, this is not a very abundant species. In most cases only one or a very few specimens have been seen from any one locality. It may be more abundant on Oahu, if one can judge from the number of specimens that have accumulated in collections. In order to help prevent further misidentification in any new areas where the species may be found, a brief description and figure are given here. The male genitalia are very distinctive. In most cases an examination of the tip of the tegmen will suffice for the identification of the species; none other has been seen with a similar conformation. A quick perusal of the British Museum collection and the Pic collection in Paris failed to disclose any species that might be likely close 
relatives, at least on external features. However, the author is not thoroughly familiar with the Old World fauna and may have missed some species.

\section{Anthicus tobias Marseul}

(Figs. I-3)

Anthicus Tobias Marseul, 1879, L'Abeille 17: 125. Pic, 1911, Coleop. Cat., pars $36: 77$.

Rufous, the antennae, palpi and legs luteous; elytra with a ferrugineous to piceous area that extends from the basal $2 / 5$ to $\mathrm{I} / 4$ to the apex, with the suture pale anteriorly, and with a very pale spot on each elytron at about I/5 from the apex. Prothorax and elytra flattened.

Head subquadrate, but base rounded and slightly notched at the middle. Surface smooth, with dense, rather small punctures throughout, even on the midline. Pubescence moderately dense and short, fine, decumbent. Eyes moderately large, prominent. Antennae slender but slightly thickened apically. Prothorax widest at apical third, flattened, with punctures and pubescence similar to those of head. Elytra subparallel, flattened; omoplates slightly elevated; suture elevated on apical half. Surface smooth, moderately densely punctured, the punctures on the basal portion slightly larger and feebly asperate, those behind fine and small. Pubescence golden in the pale zone, brown over the dark markings, decumbent, fine, directed obliquely laterally in the basal fourth, not conspicuous. Tactile setae very short but erect. Male pygidium flattened, with truncate apex; hypopy-

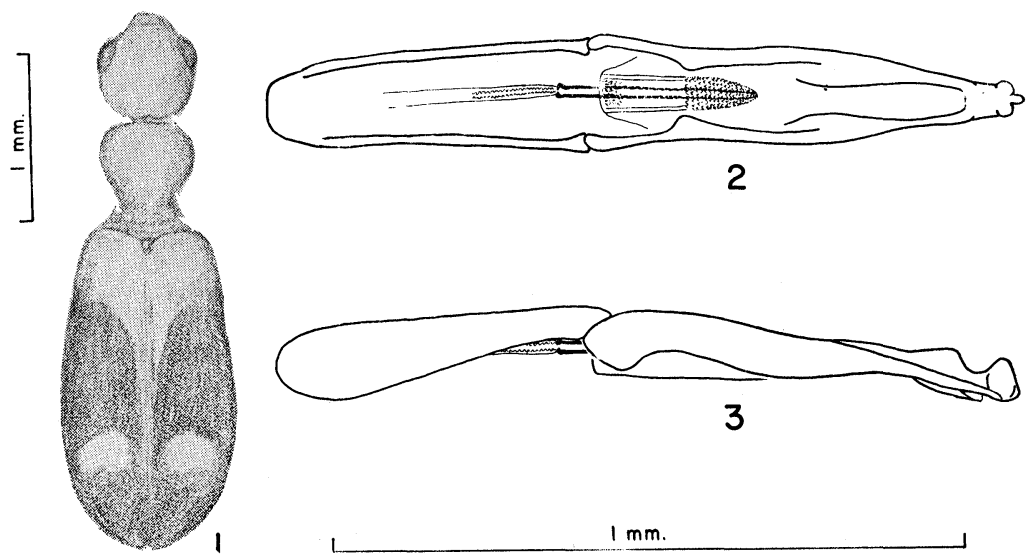

Figs. 1-3. Anthicus tobias Marseul. 1. Habitus sketch, with sculpture and pubescence omitted. 2. Aedeagus, in ventral view as it lies in the abdomen. 3. Aedeagus, in left lateral view. 
gium with a shallow, $\mathrm{V}$-shaped notch. Aedeagus with a dorsal ridge and subapical notch on the tegmen; gonopore armature very large and complex, not inverted.

The total length of the specimens examined ranges from 2.6 to $3 . \mathrm{I}$ $\mathrm{mm}$. Both the pale area at the base of the elytra and the subapical spots vary somewhat in size. The most similar-looking species in the North American fauna is Anthicus cervinus, which has curved pubescence on the elytra in most parts of its range, elytra that are not flattened, and very different male genitalia.

Range: Except for the localities followed by a bibliographic citation, the author has seen specimens from each of the following localities: ASIA : Arabia (Pic, I9II) ; W. Aden Prot.: Lahej - XI-27I937 - Scott \& Britton; Iraq (Marseul, I897); Turkestan (Pic, I9I I) ; India (Pic, I9II) and U. P.: Fyzabad - Hingston. INDIAN OCEAN: Mauritius (Pic, I9I I). E. INDIES: Java: Preange-Tijembong - 4'15 - Corporaal. PACIFIC OCEAN: Marianas: Guam: Agana $-\mathrm{X}$-10-1952 - J. W. Beardsley ; Hawaiian Islands: Oahu: Ewa - X-1958 - lt. trap; Waipio - I-22-1946 and VIII-I949 - lt. trap - Pemberton; Manoa - IX-IO-I949 - at lt. - O. H. Swezey. NORTH AMERICA: CANADA: Quebec: Granby - VI-I 5-I9I I - P. E. Mercier. U. S. A.: MASS.: Boston - VIII-I3-I9II - found dead on Boston Common - Fall Coll.; Bedford - VII-r 5-I9I I - C. A. Frost; Nahant - VI-3-I935 P. J. Darlington; Framingham - VIII-I 2-I944 - C. A. Frost; Dover - VIII-3-I949 - K. Christiansen. CONN.: Hamden VIII-25-I939 - lt. trap - N. Turner. WIS.: Wood Co. : Nekoosa - VIII-23-I948 - lt. trap - W. W. Barrett. ILL.: Chicago IX-6-I 909 - Fall Coll. and X-24-I92 I - A. B. Wolcott; LaSalle Co.: VIII-24-1936 - F. Werner, and Lowell - VIII-24-I 948 lt. trap - F. Werner \& W. Nutting. PENN.: Delaware Co. - IXro-I94I - R. C. Casselberry; Williamsport - VIII-3-1949 - at lt. D. C.: Washington - VIII-I 5-I9I I - at lt. - H. S. Barber. FLA. : Jacksonville - VI-ıO - R. L. Blickle; Broward Co.: Pineland X-1956 - L. N. Bell. ALA. : Mobile - VI-23-1950 - E. O. Wilson. TEX.: Dimmit Co.: Catarina - VII-7-1948 - at lt. - F. Werner \& W. Nutting. ARIZ.: Sierra Ancha Mts. - X-I-I925 D. K. Duncan. ORE.: Jackson Co.: Ashland - Black \& Davis. W. INDIES: Jamaica: Spanish Town - flying at dusk; Morant Bay; and Gordon Town, all II-I937 - E. A. Chapin and R. E. Blackwelder. S. AMERICA: Venezuela: Caracas - V-VI-I957 M. J. \& S. Sargent. 

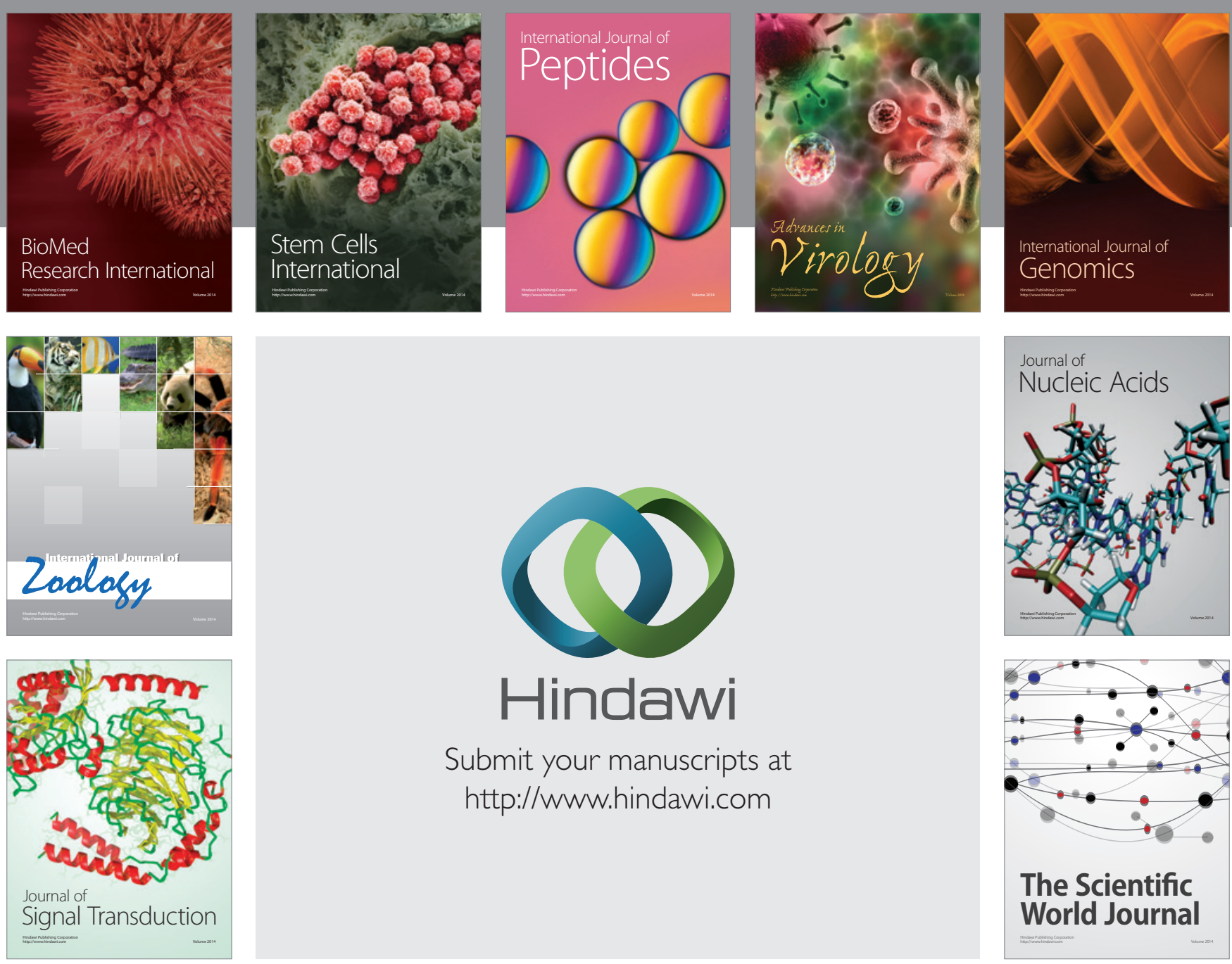

Submit your manuscripts at

http://www.hindawi.com
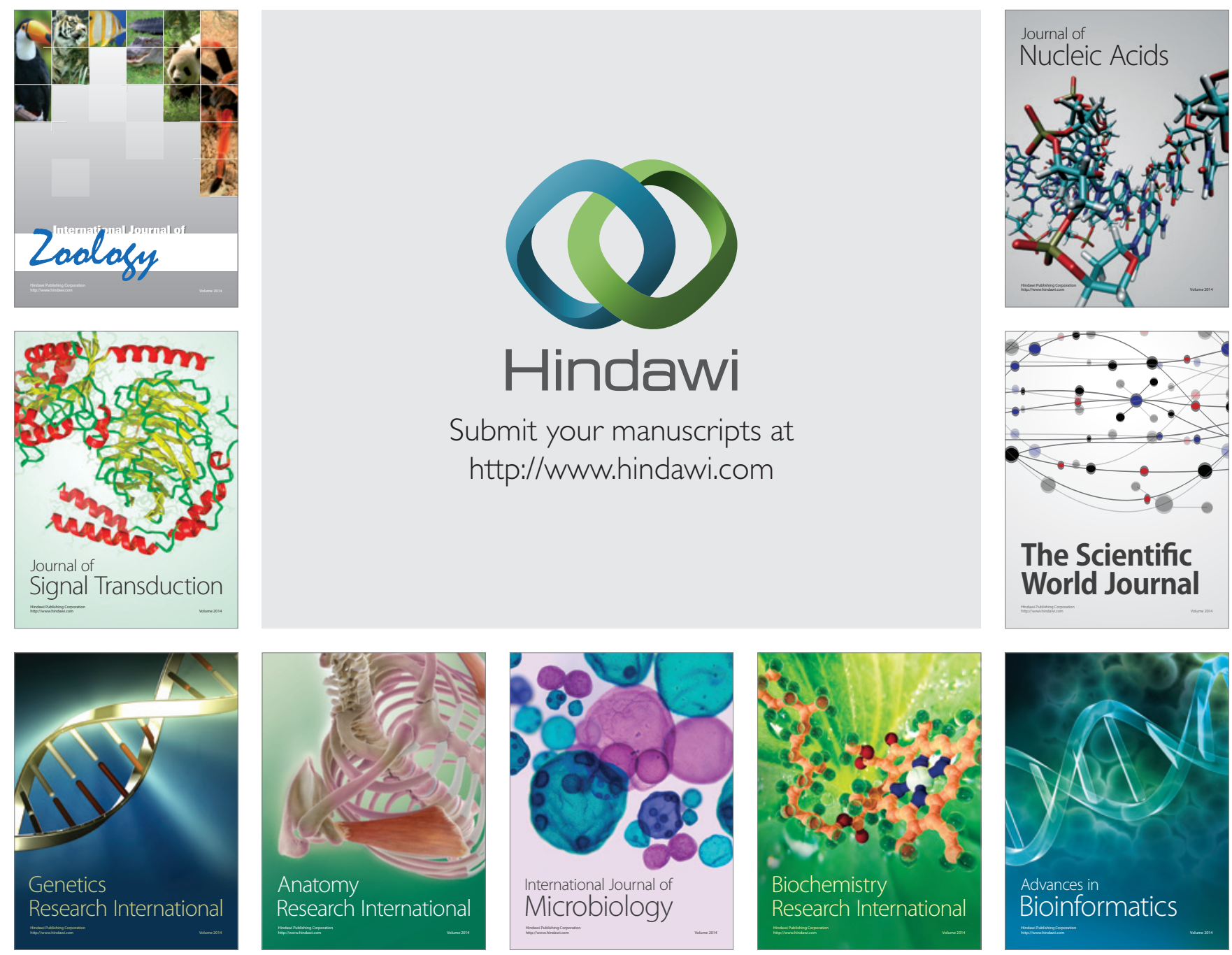

The Scientific World Journal
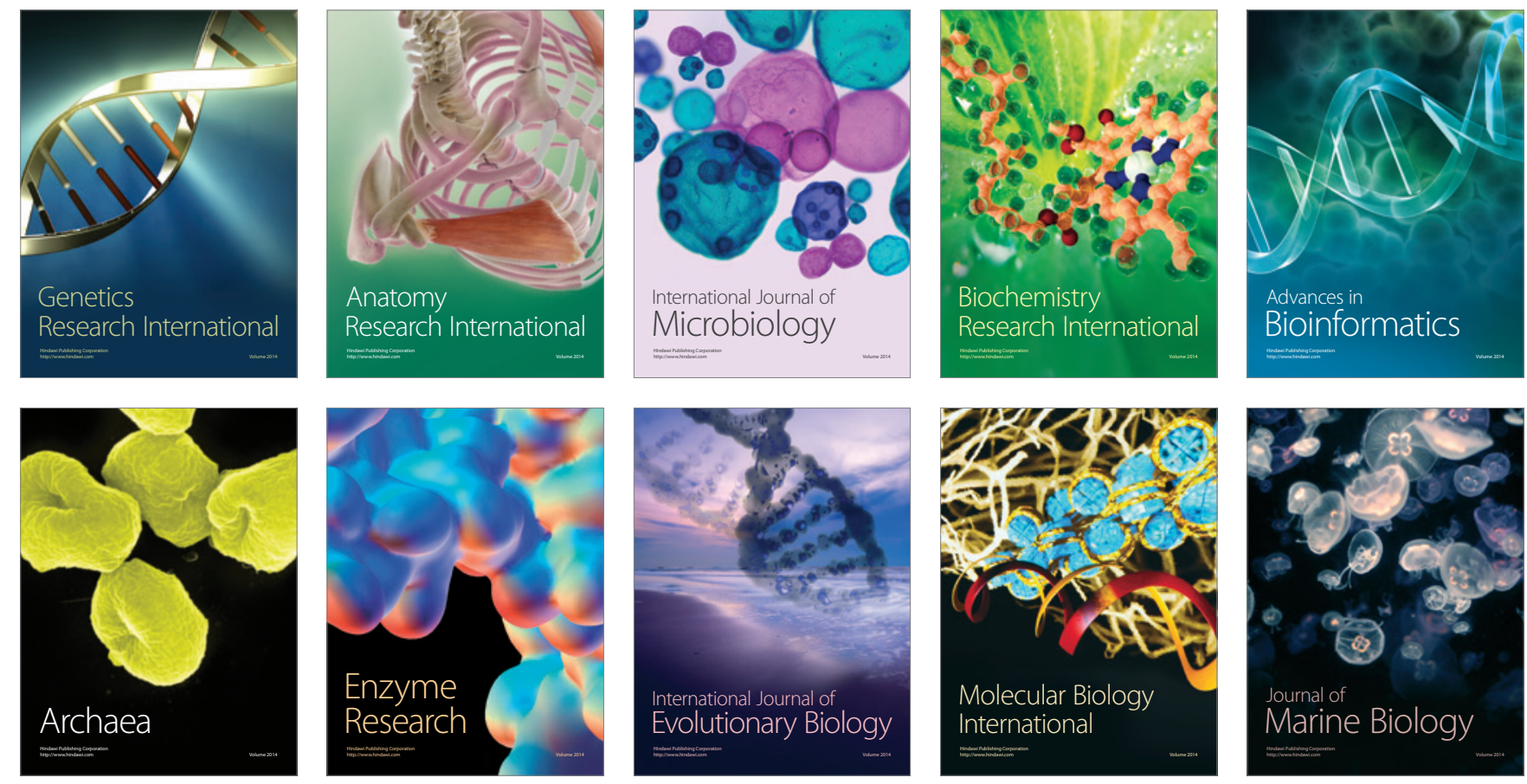